\title{
Anent J. Alfred Prufrock
}

\section{ROBERT F. FLEISSNER}

\section{$\mathbf{T}$}

he name of Eliot's anti-hero J. Alfred Prufrock is indeed an imposing one, thus ironically befitting the self-important figure for whom it is a label. Yet no attention to speak of has been paid to the aesthetic implications in the name of this "aestheticist" person, let alone to the historical sources. It has been tacitly accepted that "the name Prufrock . . . was borrowed for him by Eliot from a St. Louis family," specifically from the Prufrock-Littau Company, furniture dealers, and that that is all there is to it. Yet Eliot is on record for having said that he was not aware of any single, basic origin of the name: "I did not have, at the time of writing the poem, and have not yet recovered, any recollection of having acquired the name in this way. . . ". Since it is perfectly clear that other names of Eliot's have symbolic meanings, ${ }^{3}$ let us look more deeply into the connotations of Prufrock's full name and see what emerges. An extraordinary richness reveals itself, one that hitherto has been ignored. It is convenient to take the name in sequence, starting with the initial, then the middle name, and finally the surname.

\section{I: The First Initial}

What is Prufrock's Christian name? We do not know, only have a "secretive J." confronting us. In terms of Prufrock's problems in accepting Christianitydifficulties that Eliot himself then later resolved - the hint in the initial already points at either latent Christianity or, what is more likely, a resistance to accepting a "Christian" first name. Since Prufrock asks himself the Christ-like question of whether or not he should accept life after death (with specific reference to the miracle of Lazarus), it is possible that the "J." stands for a potential similitude with Christ, thus "J." for Jesus. Since Eliot grew up in St. Louis, he could well have been aware of the implications of the initials S.J. (Society of Jesus) following the names of Jesuits teaching at St. Louis University. Still, in terms of Prufrock's own wavering attitude toward formal religion, the initial might be taken as standing potentially for Judas as well as Jesus. There must be more, therefore, behind the initial than a hidden allusion to

'Grover Smith, Jr., T. S. Eliot's Poetry and Plays: A Study in Sources and Meaning (Chicago: University of Chicago Press, 1956), p. 17. The standard article on the matter is Stephen Stepanchev, "The Origin of J. Alfred Prufrock," Modern Language Notes, 66 (June, 1951), 400-401.

${ }^{2}$ Stepanchev, loc. cit.

${ }^{3}$ For example, Gerontion, names in Old Possum's Book of Practical Cats, the Rock (comparable with Prufrock), Marina, and The Hollow Men. It is hardly necessary to review their import here. 
religion.

Grover Smith, Jr., tells of "the somewhat precious and for America, at least, esoteric quality of his name, with its obtrusive initial $J$ " and makes the point that it recalls "the signature T. Stearns-Eliot which Eliot used." 4 Since some readers, notably Pound, felt that there was much of Eliot in Prufrock, this connection cannot be ignored. But it still does not account for the particular letter used in the initial. Why should it be so secretive or "obtrusive"? One evident reason, suggested by one of my students, is that Prufrock is the type of reticent individual who would cover up his first name simply because he did not like it, in much the same way as many persons hide their middle names with initials (including the writer of this paper). On the other hand, if Prufrock just wanted to be different or snobbish, he could have used an initial initial for no other reason than to distinguish himself from the run-of-the-mill type that uses an initial only for the middle name. I suspect that this latter reason is the one that would come to most readers' minds.

Nonetheless, there is a better reason yet, one that provides deeper insight into Prufrock's character. If he wanted to hide his first name, he may have had a very understandable reason: he may not have liked it because it had feminine or girlish connotations. Although admittedly this is a conjecture, there is some good evidence behind it.

For the conjecture to have any validity, certain questions must be raised and answered. Firstly, what basis might there have been for Eliot's having imputed girlish tendencies to Prufrock? Secondly, what kind of a girlish name might then reside behind the initial? Thirdly, how might this name have been picked up by Eliot? I believe that all these questions can be tentatively answered.

To begin with, as I mentioned earlier, it has often been accepted that there are some resonances of Eliot himself in the character of Prufrock as well as in the name. Now, a leading question regarding Eliot's personal life is whether he was bisexual. T. S. Matthews has dismissed the problem out of hand, calling the rumor of Eliot's homosexuality "easy to refute,"5 yet he has to admit that "to the anonymous, rather nasty mind of the reviewer of the Times Lit Suppl, some of the suppressed lines [of The Waste Land, recently brought to light in The New York Public Library] blow the gaff on Eliot's guilty secret: that he hated and feared women - in short, that he was a homosexual."6 Matthews' biography, however, is generally regarded as special pleading and certainly not definitive. The question of Eliot's sexual or emotional life cannot be properly answered unless John Peter's argument is reintroduced.

${ }^{4}$ Smith, p. 17.

${ }^{5}$ Great Tom: Notes Towards the Definition of T. S. Eliot (New York: Harper and Row, 1974), pp. 75-76. Matthew also notes (p. 36) that the title of The Love Song of J. Alfred Prufrock derives from Kipling (but not the name in the title).

'Matthew, loc. cit. 
The case put by John Peter ${ }^{7}$ is rather curious. Dealing with Eliot's most controversial poem, The Waste Land, Peter tells us that the object of the speaker's love is a young man who soon afterwards met his death, it would seem by drowning. The speaker himself, Tiresias (at least in most cases), ${ }^{8}$ is described in hermaphroditic terms. When Peter first suggested this interpretation in print, Eliot had it suppressed, and it was not republished until after Eliot's death, when it appeared with an introductory paper ${ }^{9}$ and alongside another discussing $\mathrm{Mr}$. Eugenides, a character in the poem often considered a decadent homosexual, and citing Peter's article in the process. ${ }^{10}$ Allusions in The Waste Land, particularly that to the "hyacinth girl" (described as having wet hair as if related to the drowned male object of the speaker's love), have been made much of, particularly now by G. Wilson Knight, who accepts Peter's interpretation. With regard to Prufrock, however, only a few of these points are relevant. Of particular interest are Peter's assertions that "we should note, I think, that Marie mentioned early in The Waste Land is on the Continent a name given to both sexes" 11 and that "as with Hallam and Tennyson, so with Jean Verdenal and Eliot. . . ."12

For the initial "J." in Prufrock's name probably stands for Jean. He was named after Jean Verdenal, who may have been Eliot's lover in Paris. The first name is covered up not only to hide the identity but because Jean is a name with feminine connotations (that is, it is male in French but female in English, an association also frequently encountered with the English names Jean and Gene, insofar as the latter may embarrass some men because it sounds the same as its feminine counterpart). Eliot dedicated both The Waste Land and Prufrock to Jean Verdenal, and he did not complete Prufrock until after his relationship with the Parisian youth who was subsequently drowned. Compare then the allusion to drowning at the end of Prufrock. Although it is impossible to know for certain whether or not Eliot invented the first initial of Prufrock's name before he met Jean Verdenal, the "J." surely assumes some of the resonance of Jean's natile if for no other reason than that the intent behind a work of literature cannot be ultimately determined until it has been completed. Prufrock clearly contains other French echoes, notably from the writings of Laforgue. And Peter points out that Eliot's dedication of The Waste Land to Jean is uncommonly fervent: "the measure of the love which warms me towards you" (in translation). ${ }^{13}$ Grover Smith indicates that though Prufrock was begun at

\footnotetext{
7". A New Interpretation of The Waste Land (1952)," Essays in Criticism, 19 (1969), 140-175.

"Stephen Spender, in T. S. Eliot (New York: The Viking Press, 1976), questions Grover Smith's view that the "I" of the poem is the Fisher King (p. 113).

${ }^{4} \mathrm{~A}$ "Postscript" by F. W. Bateson, the editor. The article first appeared in 1952 (see n. 7).

"William H. Pritchard, "Reading The Waste Land Today," Lisays in Criticism, 19 (1969), 176-192.

"Peter, p. 145. The obvious example that comes to mind is the poet Rainer-Marie Rilke.

1.Peter, p. 168.

I:Ibid., p. 169.
} 
Harvard, it was not finished till Eliot's Paris year, and that he showed his manuscript poems most probably to his new male friend he encountered at Paris, memorializing him in his dedication to Prufrock and Other Observations some four years later. Still, I would agree with Elizabeth Schneider, in her recent monograph on Eliot, that there is not enough evidence to know if the poet was homosexual or went through such a phase. Yet Prufrock and Eliot are not entirely the same, and whereas I would reject the view that Prufrock is bisexual per se, he appears latently that way. In sum, then, since it is common knowledge that Prufrock's love is either ironic and/or related more to the speaker's self than to any of the women mentioned, why should we not see it as also directed toward Jean Verdenal (spiritually at least, if not physically), whose first name subtly completes the hidden first name of J. Alfred Prufrock?

\section{II: The Middle Name}

Peter's reference to Hallam and Tennyson leads directly to a consideration of Prufrock's middle name. For does not Alfred echo Tennyson's first name? We may be tempted to consider other possibilities, like that of King Alfred perhaps, but since Prufrock disclaims being a prince, it would be presumptuous to give him a royal role, even nominally. There are actually a number of good reasons for contending that Eliot had Tennyson in mind in writing the poem and devising the name of the protagonist apart from the Eliot-Verdenal/TennysonHallam connection. Let us consider these in turn.

(1) Tennyson's own poetry, notably his Idylls of the King, has been charged with having the same kind of precious effect that Prufrock's own character evokes, indeed to the extent that Eliot's American contemporary, Edwin Arlington Robinson, decided to write his own Arthurian idylls, following Tennyson's lead but attempting to overcome the prissiness.

(2) Eliot's pronounced debt to Tennyson throughout his work cannot be ignored. He made use of Tennysonian subject matter not only in the Arthurian grail myth of The Waste Land, but in the hints that he borrowed from Maud, "The Lady of Shalott," and other lyrics, especially those dealing with the dichotomy of Art and Life, in Prufrock. ${ }^{14}$

(3) Tennyson's own difficulty in reconciling faith and doubt, in In Memoriam-a consideration that is now best recalled through Eliot's familiar critique of that elegy as more memorable for the quality of its doubt than that of its faith-is intimated also in Prufrock.

(4) Most obviously, Eliot wanted to follow in the Victorian Poet Laureate's footsteps and thus, in Alfred Prufrock, appropriated Tennyson's first name. The infernal setting of the poem in a macabre but delightful way recalls the story

\footnotetext{
${ }^{14}$ See W. K. Wimsatt, Jr., "Prufirock and Maud: From Plot to Symbol," reprinted in Hateful Contraries: Studies in Literature and Criticism (Lexington: University of Kentucky Press, 1965). pp. 201-212: also Donald J. Weinstock, "Tennysonian Echoes in 'The Love Song of J. Alfred Prufrock," English Language Notes, 7 (March, 1970), 213-214. Neither article deals with any influence of nomenclature.
} 
about Tennyson's Calvinist aunt who informed her Alfred that looking at him reminded her of the biblical text about sinners damned to everlasting fire.

(5) Finally, and most importantly, if Prufrock appropriated Tennyson's first name as his middle name via Eliot, what happened to Tennyson's own middle name? It too was appropriated. It must be recalled that Prufrock goes out of his way to stipulate that he is not "Prince Hamlet, nor was meant to be"; instead Alfred was meant to be "an attendant lord." Alfred Lord Tennyson. The resonance is clear.

\section{III: The Surname}

Prufrock's last name is more complicated. Stephen Stepanchev tells us that "the name Prufrock is so rare that a thorough search of the telephone directories of fifteen other large American cities [other than St. Louis] failed to discover a single representative of the family." 15 And Eliot's refusal to admit that he borrowed the name from real life suggests that it is more than a "representative name." There are undoubtedly psychological overtones. As George Williamson writes, "in this poem. . .we have the love song of a certain character, whose very name is suggestive of qualities he subsequently manifests." "He goes on to note, rather too cavalierly, that "if Eliot's proper names do not acquire meaning from history or literature or etymology, they are used for their generic or social suggestion." names, for example in Gerontion, do have etymological suggestiveness: "But can it be fortuitous that these names, enumerated in connection with the Eucharist, nearly all of them carry a religious suggestion (de Silvero: thirty pieces of silver. De Tornquist: the Crown of Thorns and the Thorn in the Flesh. Von Kulp: culpa)?"

Elsewhere I have suggested that the surname is portmanteau, in Lewis Carroll's use of the term, but that rather than considering the combination effect as pointing to a "prude in a frock," with the womanly and even clerical19 connotations implied by such a conflation, the more serious reader would think of the speaker's quest for "proof of rock," for a firm foundation for his wavering beliefs. ${ }^{20}$ This distinction is, I believe, a good one still to maintain critically, particularly because it elicits positive rather than merely negative facets of the protagonist's personality. But there is more involved in the surname than such name-play. Thus, I have also considered, in a different article, the affinity of the

\footnotetext{
is Stepanchev, loc. cit.

"A Reader's Guide to T. S. Eliot: A Poem-by-Poem Analysis, 2nd ed. (New York: Farrar, Straus and Giroux, 1969), p. 58.

${ }^{17}$ Ibid.

${ }^{18}$ See the review of Williamson by C.A. Bodelsen in English Studies, 35 (1954), 90.

${ }^{19} \mathrm{Cf}$. "de-frocked."

2"See my review-article of John Harrison's The Reactionaries: A Study of the Anti-Democratic Intelligentsia entitled "Reacting to The Reactionaries: Libertarian Views," in Journal of Human Relations, 17 (First Quarter, 1969), 138-145.
} 
name Prufrock with that of Touchstone; ${ }^{21}$ that is, to touch a stone for proof of rock makes some sense too. When we take into account that both Prufrock and Touchstone were described in anti-romantic ways (at least insofar as Prufrock's hesitancy to accept women is concerned) and that Touchstone, as a court clown, may represent the "fool" that Prufrock admits to being sometimes, the parallel does not seem overly far-fetched. It has recently been suggested to me ${ }^{22}$ that the name Prufrock could just as well, or better, derive from that of Montefeltro, however, in that this name in the poem's epigraph suggests a combination of the Italian monte (mountain) with English felt ${ }^{23}$ - thus "proof of rock" in the sense of a mountain that is felt! But that association, aside from the humor it evokes, has not much to do with the poem except insofar as both Prufrock and Montefeltro inhabit their own infernos. An even more amusing suggestion, I submit, is that the portmanteau effect of Prufrock's name recalls that of some of Dickens' characters, notably David Copperfield. For we all know (or should, I suppose) that Eliot found Copperfield second only to War and Peace, and is not a "field of copper" "proof of rock" too? Obviously this suggestion cannot be taken seriously, but I reject the association with Dickens' own leading autobiographical work only with regret because there seem to be other Copperfieldean elements in Prufrock. ${ }^{24}$ Moreover, there is much that is Dickensian about Eliot's poem, ${ }^{25}$ like the animism in the yellow fog that acts in a manner recalling not only Carl Sandburg's fog but various scenes in Dickens, for instance the wind at the outset of Martin Chuzzlewit. The name Prufrock seems to reflect other Dickensian names somewhat, such as Podsnap (also in Chuzzlewit) and Chadband. There is a decidedly Victorian quality about both Dickens' and Eliot's names; the hypocritical quality is evident in their very pretentious sonorousness.

From a Gestaltist point of view, Prufrock's last name is certainly more important than his first two. If there is, as I have indicated, an indication of hushed-up girlishness in the initial, of further preciousness in the hint of Tennyson in the middle name, there is at least a comic ${ }^{26}$ conclusion in the

\footnotetext{
21 "Prufrock as Touchstone" (reply to query-note), American Notes and Queries, 11 (December, 1972), 56-57.

2-By Prof. Richard Knowles of the University of Wisconsin (Madison).

${ }^{23}$ The Italian word feltro, which refers to felt in the sense of a felt hat, would have no symbolic value here.

${ }^{24}$ There are allusions to Lazarus and Hamlet in the opening two chapters of this novel, ones which curiously parallel the same association in Prufrock. Moreover, the character of Littimer in Chapter XXI, described as "deferential, observant, always at hand when wanted," looks ahead to Prufrock "Deferential, glad to be of use." Littimer places great importance on his watch, suggesting Prufrock's concern about time; his "pattern of respectability" suggests Prufrock's, and that "no one knew his Christian name" invites comparison with Prufrock's first initial. Littimer is also a kind of "attendant lord," waiting on Steerforth. (Was Old Possum full of . . Dickens?)

25 It is now well known that Eliot's original title for The Waste Land was "He Do the Police in Different Voices," taken from Dickens. For more on Prufrock and Dickens, see Barbara Everett, "In Search of Prufrock," Critical Quarterly; 16 (Summer 1974), 101-121.

${ }^{26}$ In The Overwhelming Question: A Study of the Poetry of T.S. Eliot (Toronto: University of Toronto Press,
} 
Dickensian effect of the last name. For Prufrock is indeed after "proof of rock" in a Touchstone-like way, but he never makes it, ending up ironically as a kind of "prude in a frock" in spite of himself. Behind the pretentiousness and effeminacy, however, a man is trying to assert himself, and that man is T. S. Eliot. It is not until he finds himself in his later work that his quest approaches completion, but a modest start was made shortly after Prufrock was finally completed. For at that time Eliot entered into his first marriage. Whatever his earlier dissipations, ${ }^{27}$ he tried to mend his ways, for the weakness of Prufrock is shunted aside in favor of a stronger sense of individuality and a deliberate acceptance of political, religious, and poetical values.

\section{Central State University}

1976), which is one of the most interesting studies of his work to appear in some time, Balachandra Rajan argues that Prufrock must be considered as largely in the comic mode.

"After this paper was accepted, George Watson's interesting article on Jean Verdenal, "Quest for a Frenchman," appeared in "The State of Letters" section of The Sewanee Review, 84 (Summer 1976), 465-475. Watson objects to hints of Eliot's friend in The Waste Land (a view which has now also been accepted by Robert Sencourt, Eliot's Catholic friend and biographer, in his T. S. Eliot: A Memoir)on the grounds that Verdenal did not drown and that "there is no reason to suppose that Eliot ever thought he was drowned" (p. 473). I question that last statement. True, Eliot's dedication to Prufiock and Other Observations, "For Jean Verdenal, 1889-1915/ mort aux Dardanelles," could mean at the Dardanelles and not in the Dardanelles, but the poet's later reference to the friend in the Criterion of April 1934 suggests that at the time Eliot wrote the dedication, at least, he thought the Frenchman had drowned: "a friend who was later (so far as I could find out) to be mixed with the mud of Gallipoli" (cited by Watson, p. 466, with my italics). The phrase "mud of Gallipoli" ( a seaport) suggests, to me at least, water; otherwise, if Eliot had known his friend was presumably shot while ashore, he would have said "dirt," for it is unlikely that there were battlefields of mud at a seaport. Moreover, the kinship between his description of the friend ("waving a branch of lilac") and the crux in The Waste Land "they called me the hyacinth girl" is certainly curious, if not absolutely factual. Further, would not Eliot, in his far-ranging poetic mind (and having composed Prufrock when William James's theories of mental associations were dominant at Harvard), have linked death and the Dardanelles with death and the Hellespont, hence with the drowning of the lovers Hero and Leander in the same straits? That the most famous lyric about this mythic love affair was written by an avowed homosexual, Christopher Marlowe, from whose The Jew of Malta Eliot quoted elsewhere in a headnote, would not have escaped his attention. Watson also contends that "Eliot's sympathy for the emotional difficulties of a homosexual friend, for which an anecdote at second hand is quoted by Mr. Peter in the postscript of 1969, is hardly evidence for anything more than Eliot's kindliness of heart" (p. 473); however, aside from the matter of authenticity, the anecdote pointedly provides some evidence for Eliot's having had "a homosexual friend." Although l tend to agree that the washing of dirty linen in public is not always commendable (though its fascination with regard to famous men of letters cannot be denied either), I see nothing wrong in separating the person from the persona to the extent of noticing hints of male friendship in what Eliot wrote. Naturally I cannot profess to pass judgment on his personal life, except to suggest that some of it was sensibly sublimated in his art. In the same manner, Elisabeth Schneider has questioned whether Eliot's early poem The Death of Sain Narcissus had any such hidden meanings; however, the Narcissus symbol is used with such meanings in Death in Venice. Eliot's likewise sequestered lyric King Bolo and His Big Black Queen (which, like Peter's article in Essays in Criticism, Eliot did not want to have published) has unmistakable reference to hisexual hawdiness (e.g. . "airy fairy hairy "un "/."Cardinal Bessarion"). At the time of writing. I had not yet seen James E. Miller's new study. T.S. Fliot's Personal Waste L.and: Exorcism of the Demons (University Park: Pennwhania State (Iniversity Press. 1977). 